\title{
Suppression by Methionine of Reversions to Adenine Independence in Schizosaccharomyces pombe
}

\author{
By C. H. CLARKE \\ M.R.C. Mutagenesis Unit, Institute of \\ Animal Genetics, Edinburgh, 9
}

(Received 13 August 1962)

\section{SUMMARY}

Spontaneous mutations, and those induced by nitrous acid or ultraviolet light, were studied in the haploid fission yeast Schizosaccharomyces pombe. Reverse mutations conferring ability to grow on a minimal medium lacking adenine were scored in adenine auxotrophs, and in di-auxotrophs having requirements for both adenine and methionine. The apparently lower mutability of the ad-1 mutants in the $a d^{-}$-met- diauxotrophic strains compared with the $a d^{-}$strains was shown to be due to the influence of methionine in the plating medium. L-methionine added to the minimal medium at a concentration of $40 \mu \mathrm{g}$. per ml. will suppress the appearance of spontaneous and induced revertants of adenine-1 mutants. A similar effect has been shown for reversions of an adenine mutant at another locus, and for reversions of a leucine auxotroph. Methionine has the effect of decreasing the extent of residual divisions undergone by adenine-requiring cells when plated on a minimal medium.

\section{INTRODUCTION}

Several examples have been found in micro-organisms where change of the genetic background markedly alters the ability of a particular mutant to undergo spontaneous and induced reversion. Glover (1956) quoted several cases in Escherichia coli where reversions of one particular auxotroph were influenced to a considerable degree by the presence or absence of other auxotrophic or drug-resistance markers in the same strain. Witkin \& Theil (1960) found that a particular trytophan auxotroph of $E$. coli which reverted strongly after treatment with u.v. light would no longer do so if a marker for streptomycin-dependence was introduced into the strain. The most dramatic examples of the influence of genetic background upon mutability are found in microbial strains carrying a mutator gene. This latter may have a profound effect on the spontaneous mutability of many other loci (Treffers, Spinelli \& Belser, 1954; Miyake, 1960).

In the present work, investigations were made of spontaneous and induced reverse mutations from requirement to non-requirement for adenine $\left(a d^{-} \rightarrow a d^{+}\right)$in strains of the haploid fission yeast Schizosaccharomyces pombe. The genetics of this organism have been studied extensively by Leupold $(1955,1958,1961)$, and reverse mutation experiments were carried out by Heslot $(1960,1962)$ and Fritz-Niggli (1960). In the work to be described $a d^{+}$reversions were scored both in strains having adenine as the only requirement, and in strains requiring both adenine and methionine $\left(a d^{-} \mathrm{met}^{-}\right)$. The influence of the met- marker on the mutability of the 
$a d^{-}$mutants was investigated. The results obtained led to an explanation at a physiological level of an apparent influence of genetic background on mutability.

\section{METHODS}

Strains of Schizosaccharomyces pombe. Ten mutants located at the adenine-1 locus were kindly provided by Professor U. Leupold. These mutants were produced by u.v. irradiation of a wild-type strain (Leupold, 1955). They are blocked at an early step in the biosynthesis of adenine, before the formation of 5-aminoimidazole ribotide (Leupold, 1961), and do not accumulate a red pigment when grown in limiting concentrations of adenine. These ten ad-1 mutants are located at ten different sites within the locus (Leupold, Ramirez \& Clarke, unpublished results). Most of the experiments were carried out with three mutants, numbers 3, 25 and 40.

Mutants at other loci were provided by Professor U. Leupold, Dr H. Heslot and Mr R. B. Drysdale. Doubly auxotrophic strains requiring both adenine and methionine were isolated from crosses between the singly auxotrophic strains. Except where otherwise stated mutants used in experiments were of the $h^{-}$heterothallic mating type.

Complete media. For growth in liquid culture YE medium was used containing 'Difco' Bacto Yeast Extract 5 g., D( +) glucose 30 g., distilled water 1000 ml. For growth of adenine auxotrophs this medium was supplemented with adenine sulphate, $50 \mathrm{mg} . / \mathrm{l}$. (YE + Ad). Cultures on solid medium were grown on 'Oxoid' Yeast Extract Agar with the addition of $3 \%(w / v)$ glucose, and adenine $50 \mathrm{mg}$./1. (YEA+ Ad).

Minimal medium (MMA). The minimal medium agar used was that of Leupold (1955), but with glucose added to $2 \%(\mathrm{w} / \mathrm{v})$. 'Ionagar No. 2' (Oxoid) was added to a concentration of $1.6 \%(w / v)$.

Buffer (GSVB). Giese's modification of Reader salts solution (Giese, Iverson \& Sanders, 1957; Reader, 1927) was used, with the addition of $\mathrm{KH}_{2} \mathrm{PO}_{4}$ to a concentration of $0.05 \mathrm{M}(6.8 \mathrm{~g}$./1.) and of the four vitamins essential for Schizosaccharomyces pombe.

Reverse mutations. Cells for mutation experiments were harvested by centrifugation from aliquots of $80 \mathrm{ml}$. YE + Ad cultures grown with aeration for $48 \mathrm{hr}$. at $30^{\circ}$ in $250 \mathrm{ml}$. flasks. Cultures were inoculated from colonies on YEA + Ad plates. Aeration was provided by a gentle stream of sterile filtered air.

The cells were resuspended in GSVB, pre-warmed when necessary. For treatment with alkylating agents the cells were resuspended in distilled water plus essential vitamins, and washed after treatment to remove the chemical.

Treatment with nitrous acid was carried out in GSVB suspension pre-warmed to $25^{\circ}$ by the addition of a calculated volume of a sterile $5 \mathrm{~m}$-solution of $\mathrm{NaNO}_{2}$. Routinely the final concentration of $\mathrm{NaNO}_{2}$ was $0 \cdot 1 \mathrm{M}$, and the treatment was carried out in a $25^{\circ}$ water bath.

For u.v. irradiation $5 \mathrm{ml}$. samples of GSVB suspensions at room temperature were pipetted into sterile $5 \mathrm{~cm}$. diam. Petri dishes. Irradiation was carried out at a distance of $42 \mathrm{~cm}$. from the source, a Phillips $15 \mathrm{w}$ TUV tube. The output of this source in ergs $/ \mathrm{mm}^{2} / \mathrm{sec}$. is not known. The suspensions were agitated throughout irradiation by means of a Towers-Gibson vibro shaker. All procedures during and following irradiation were carried out in yellow light to avoid photo-reactivation. 
After treatment 0.1 or $0.2 \mathrm{ml}$. samples of cell suspensions, and of $10^{-1}$ dilutions, were spread on the surface of MMA plates, supplemented when necessary with growth factors. Plating of the $10^{-1}$ dilution samples allowed a check to be made for the absence of suppression of revertant colonies by excess auxotrophs (Grigg, 1952). Serial dilutions were made in GSVB and $5 \times 0.2 \mathrm{ml}$. samples of $10^{-5}$ dilutions were plated on supplemented MMA to assay viable count. Plates were left at room temperature for $1 \mathrm{hr}$. to absorb surface moisture, then incubated at $30^{\circ}$. Revertant colonies which approached wild-type in size were scored after $\mathbf{7}$ days.

\section{RESULTS}

In experiments with singly auxotrophic $a d^{-}$strains and with doubly auxotrophic $a d^{-}$met strains it was observed that the frequency of appearance of spontaneous $a d^{+}$ revertants was appreciably lower in the $a d^{-} m e t$ than in the $a d^{-}$strains. The results for spontaneous reversions of mutants $a d-1,3$ and $a d-1,40$ are shown in Fig. 1, unshaded columns $\mathbf{A}, \mathbf{C}, \mathbf{A}^{\prime}$ and $\mathbf{C}^{\prime}$. The lower frequency of spontaneous $a d^{+}$ revertants in $a d^{-} m e t^{-}$strains compared with $a d^{-}$strains was found also for induced revertants. Results for reversions of mutant $a d-1,40$ induced by nitrous acid are shown in Fig. 1, unshaded columns $\mathrm{A}^{\prime \prime}$ and $\mathrm{C}^{\prime \prime}$.

Before concluding that the lowered mutability of the $a d-1$ mutants in the $a^{-}{ }^{-}$met $^{-}$ strains was due to the influence of the genetic background, it seemed essential to test the effect of plating media upon survival and the expression of reversions. In the singly auxotrophic $a d^{-}$strains, survival is assayed on minimal medium plus adenine, and $\mathrm{ad}^{+}$revertants are scored on minimal medium. In the $a d^{-}$met- strains, however, survival is assayed on minimal medium plus adenine and methionine, and $\mathrm{ad}^{+}$revertants on minimal medium plus methionine.

Tests were made of the influence of methionine in the plating media upon the survival of the singly auxotrophic $a d^{-}$cells, and upon the expression of $a d^{+}$ reversions in $a d^{-}$strains. Methionine added to the plating medium was without obvious influence upon the ability of $a d^{-}$cells to grow in the presence of adenine. This was true both for untreated cells and for those which had been treated with a mutagen.

Influence of methionine upon revertants of $\mathrm{ad}^{-}$strains. Although methionine in the plating medium exerted no influence on the survival of $a d^{-}$cells when adenine was also present, there was an obvious effect on the expression of $a d^{+}$revertants (Clarke, C. H. 1962, Microbiol. Gen. Bull. 18, 7). The numbers of spontaneous and induced $a d^{+}$revertants were consistently higher on minimal medium than on minimal supplemented with methionine. These results are shown in Fig. 1 and Table 1. The suppressive effect of methionine upon the appearance of $a d^{+}$colonies is not dependent on the dose of mutagen used as judged by percentage survival of $\mathrm{ad}^{-}$cells.

Delayed addition of methionine. Since methionine added to the minimal medium suppressed the appearance of $a d^{+}$revertant colonies, experiments were carried out to determine at what stage of the 7-day incubation period methionine exerted its effect. These experiments involved delayed additions of methionine to plates of minimal medium on which untreated or treated cells of $a d^{-}$mutants had been spread. After known periods of incubation at $30^{\circ}$, concentrated L-methionine solution was pipetted into small wells cut in the agar, sufficient to give a final 
concentration of about $40 \mu \mathrm{g} . / \mathrm{ml}$. in the minimal medium. After $1 \mathrm{hr}$. at room temperature the plates were then re-incubated at $30^{\circ}$ until the end of the 7 -day period.

Figure 2 shows the influence of delayed addition of methionine on revertants of mutant $a d-1,40$ induced by nitrous acid. It will be seen that the extent of the

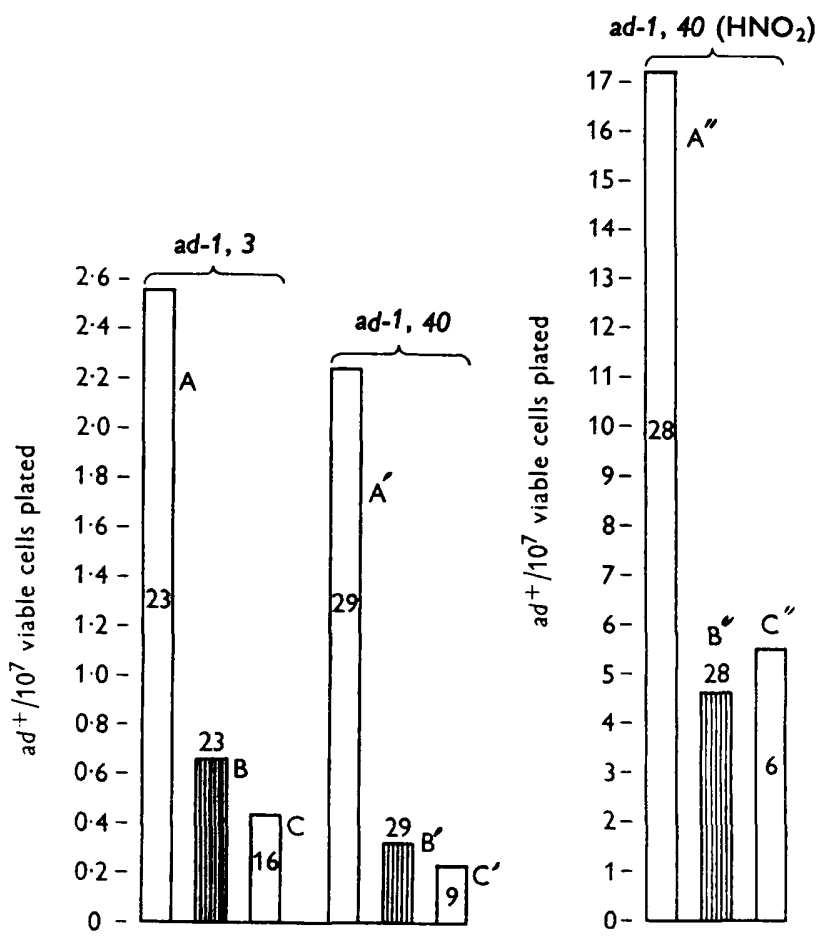

Fig. 1. Reversions of $a d-1,3$ and $a d-1,40$. Columns $A$ and $\mathbf{A}^{\prime}$ unshaded. Spontaneous $a d^{+}$revertants of $a d-1,3$ and $a d-1,40$ respectively, scored on minimal medium (MMA). Column $A^{*}$ unshaded. Nitrous acid-induced reversions of ad-1, 40 scored on minimal medium. Mean survival from 28 estimations $=75 \cdot 2 \%$. Columns $B$ and $B^{\prime}$ shaded. Spontaneous $\mathrm{ad}^{+}$revertants of $a d-1,3$ and $a d-1,40$ scored on minimal medium supplemented with $\mathrm{L}$-methionine at $40 \mu \mathrm{g}$./ml. (MMA + Met.) Column B" shaded. Nitrous acidinduced reversions of ad-1, 40 scored on MMA + Met medium. Mean survival (28 estimates) $=75 \cdot 2 \%$. Columns $C$ and $C^{\prime}$ unshaded. Spontaneous revertants of $a d-1,3$ and ad-1, 40 in $a d^{-}$met $^{-}$di-auxotrophic strains. $A d^{+}$revertants scored on MMA +Met medium. Column $C^{\prime \prime}$ unshaded. Nitrous acid-induced reversions of ad-1, 40 scored in the ad-met- di-auxotrophic strain on MMA + Met medium. Mean survival (6 estimates) $=79.5 \%$. Heights of the columns represent numbers of $a d^{+}$revertants per $10^{7}$ viable cells plated. Numbers within or directly above columns represent the number of estimates upon which the results are based.

suppressive effect of methionine on $\mathrm{ad}^{+}$revertants decreased with increasing periods of incubation before methionine addition. After about $100 \mathrm{hr}$. of incubation the addition of methionine has no influence on the numbers of $a d^{+}$revertants scored.

A similar effect is seen for spontaneous revertants of $a d^{-}$mutants which arise during the period of incubation on the MMA plates, though the graph is less precise due to the smaller numbers of $a d^{+}$colonies scored. 
Influence of methionine upon colony formation from single cells. Since methionine inhibited the appearance of $a d^{+}$revertant colonies, an investigation was made to determine at what stage of the mutagenic sequence methionine exerted its influence. The last step in the sequence is the growth of a single phenotypically $\mathrm{ad}^{+}$cell into a visible colony. Reconstruction experiments were carried out to see if methionine inhibited this last process. Small numbers of wild-type cells, or of $a d^{+}$revertant cells, were mixed with a large known excess of $a d^{-}$cells. These mixtures were plated at various cell densities both on minimal medium and on minimal medium supplemented with methionine. The results obtained indicated that methionine has no significant influence on the growth of single phenotypically $a d^{+}$cells into visible colonies, even in the presence of a large excess of $a d^{-}$cells. It was concluded that methionine must exert its inhibitory action at some earlier step in the mutagenic sequence than that of colony formation.

Table 1. Influence of methionine upon reversions to adenine independence

\begin{tabular}{|c|c|c|c|c|c|c|c|}
\hline \multirow[b]{2}{*}{ Strain } & \multirow[b]{2}{*}{$\begin{array}{l}\text { No. of } \\
\text { esti- } \\
\text { mates }\end{array}$} & \multirow[b]{2}{*}{ Mutagen } & \multirow[b]{2}{*}{$\begin{array}{c}\text { Mean } \\
\text { survival } \\
(\%)\end{array}$} & \multicolumn{2}{|c|}{$\begin{array}{l}\text { Minimal medium } \\
\text { (MMA) }\end{array}$} & \multicolumn{2}{|c|}{$\begin{array}{c}\text { Minimal+ } \\
\text { methionine } \\
\text { (MMA+Met) }\end{array}$} \\
\hline & & & & $\begin{array}{c}\text { Actual } \\
\text { no.* } \\
a d^{+}\end{array}$ & $\begin{array}{c}A d^{+} / \mathbf{1 0}^{7} \\
\text { viable } \\
\text { cells } \\
\text { plated }\end{array}$ & $\begin{array}{c}\text { Actual } \\
\text { no.* } \\
a^{+}\end{array}$ & $\begin{array}{c}A d^{+} / 10^{7} \\
\text { viable } \\
\text { cells } \\
\text { plated }\end{array}$ \\
\hline$a d-1,3$ & 23 & Spontaneous & 一 & 688 & $\mathbf{2} \cdot \mathbf{5 5}$ & 185 & $0 \cdot 65$ \\
\hline$a d-1,3 . m e t-4, D 19$ & 16 & Spontaneous & 一 & - & - & 106 & 0.43 \\
\hline$a d-1,25$ & 11 & $\mathrm{HNO}_{2}$ & 77 & 272 & $10 \cdot 6$ & 8 & 0.41 \\
\hline$a d-1,40$ & 29 & Spontaneous & - & 417 & $\mathbf{2 \cdot 2 4}$ & $\mathbf{5 5}$ & 0.32 \\
\hline ad-1, 40.met-4, D19 & $\boldsymbol{9}$ & Spontaneous & - & - & - & 16 & 0.23 \\
\hline$a d-1,40$ & 28 & $\mathrm{HNO}_{2}$ & $75 \cdot 2$ & 2106 & $17 \cdot 2$ & 632 & $4 \cdot 56$ \\
\hline$a d-1,40$. met-4, D 19 & 6 & $\mathrm{HNO}_{2}$ & $79 \cdot 5$ & - & - & 208 & $5 \cdot 48$ \\
\hline$a d-1,40$ & 18 & u.v. & $73 \cdot 2$ & 521 & $4 \cdot 04$ & 100 & $0 \cdot 69$ \\
\hline$a d-1,169$ & 10 & $\mathrm{HNO}_{2}$ & $91 \cdot 6$ & 74 & $1 \cdot 42$ & $\mathbf{3}$ & $0 \cdot 04$ \\
\hline$a d-1,199$ & 19 & $\mathrm{HNO}_{2}$ & $72 \cdot 1$ & 922 & $14 \cdot 2$ & 735 & $11 \cdot 6$ \\
\hline ad-1, 199 & 10 & u.v. & $72 \cdot 1$ & 345 & $4 \cdot 8$ & 20 & $0 \cdot 15$ \\
\hline
\end{tabular}

* Uncorrected number of $a d^{+}$colonies scored. If all the plates of a series could not be scored then the actual number scored on the remaining plates is given.

Investigations of events occurring on the plates. Experiments were performed involving observations of the residual divisions undergone by $a d^{-}$cells when they were incubated on plates of minimal medium or minimal medium plus methionine. Untreated cells, and cells treated with nitrous acid, were spread at a density of about $5 \times 10^{3}$ cells per plate, incubated at $30^{\circ}$ and observations made under $\times 320$ magnification after known periods of time. Initially most of the cells occurred singly, but later divided to form small groups of cells (Bertani, 1951). Figure 3 shows residual divisions of $\mathrm{HNO}_{2}$-treated cells of mutant ad-1, 40. Clearly the presence of methionine in the plating medium greatly inhibits the residual divisions undergone by the $a d^{-}$cells.

Actually the agar present in the minimal medium, Ionagar No. 2, contains trace amounts of adenine (M. Luzzati, personal communication), and the residual divisions may be due to this fact. It must be pointed out that residual divisions were followed on plates bearing only some $5 \times 10^{3}$ cells. Revertants are scored on 
plates bearing $10^{6}$ or $10^{7}$ cells. Thus the extent of residual divisions actually observed may not be the same as the residual divisions on the plates upon which $a d^{+}$colonies are scored.

If one or two divisions are required after treatment with nitrous acid before an $a d^{+}$reversion is phenotypically expressed (Rudner, 1961) then methionine might well decrease the number of $a^{+}$revertants scored, simply by inhibiting the residual divisions of $a d^{-}$cells.

Differential survival of $\mathrm{ad}^{-}$cells in the presence and the absence of methionine in the minimal medium. Since methionine inhibited the residual divisions undergone by $a d^{-}$cells on the minimal medium plates, tests were made to see if such cells remained viable to the same extent both on minimal medium and on minimal plus methionine. Aliquots of $0.2 \mathrm{ml}$. of $10^{-5}$ dilutions of suspensions of untreated $\mathrm{ad}^{-}$ cells, and of cells treated with nitrous acid, were spread on plates of minimal

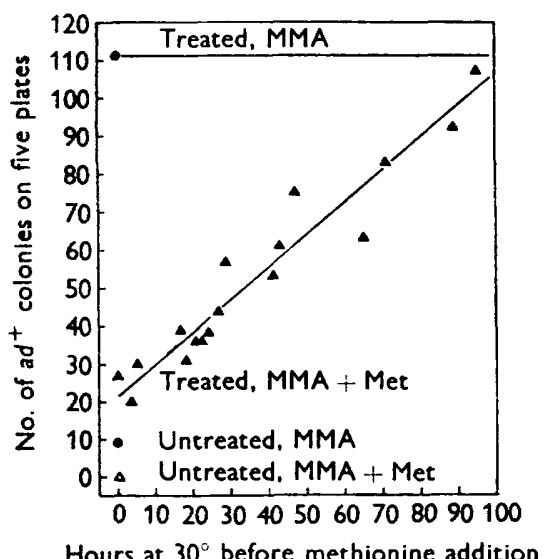

Fig. 2

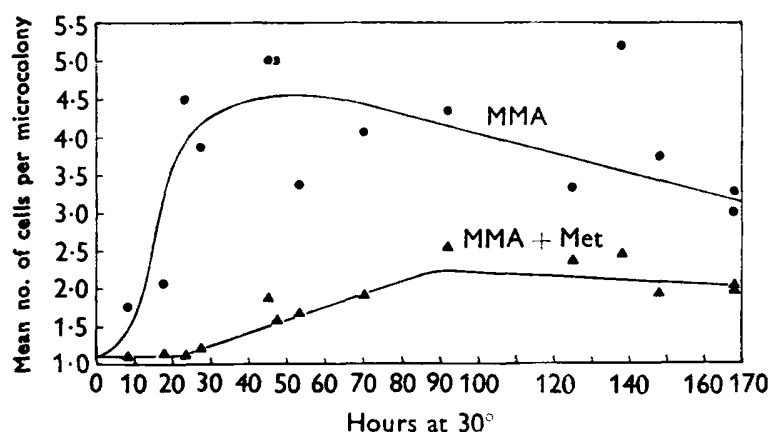

Fig. 3

Fig. 2. The influence of delayed addition of methionine on $\mathrm{HNO}_{2}$-induced reversions of mutant $a d-1,40$. Numbers of $a d^{+}$revertant colonies appearing after 7 days' incubation at $30^{\circ}$ on five plates are plotted against time in hours before MMA plates received delayed addition of methionine. Untreated series. $1 \cdot 17 \mathrm{ad}+$ reversions per $10^{7}$ viable cells plated on minimal medium (MMA) but no $a^{+}$reversions per $10^{7}$ viable cells plated on MMA+ methionine. Treated series. HNO, $98 \cdot 6 \%$ survival. 14.6 $\mathrm{ad}^{+}$reversions per $10^{7}$ viable cells plated on MMA. 3.57 $\mathrm{ad}^{+}$reversions per $10^{7}$ viable cells when plated initially on MMA+ Met medium. $\Delta=$ MMA plates bearing $\mathrm{HNO}_{2}$-treated cells which received delayed methionine additions. $=$ MMA plates bearing cells which received no delayed addition of methionine. $\triangle=$ untreated cells on MMA + Met plates, i.e. methionine present throughout the 7 -day period of incubation.

Fig. 3. Residual divisions of $a d-1,40$ cells treated with nitrous acid (98.6\% survival) on minimal (MMA) and MMA + methionine plates incubated at $30^{\circ}$. Mean number of cells per microcolony is plotted against hours of incubation at $30^{\circ}$. $\Delta=\mathrm{MMA}+\mathrm{Met}$ plates. = MMA plates.

medium and of minimal medium supplemented with methionine. Plates were incubated at $30^{\circ}$ and after known periods of time sets of five minimal and five minimal plus methionine plates received delayed additions of adenine. This was carried out by spraying a sterile aqueous solution of adenine hydrochloride (1 mg./ $\mathrm{ml}$.) on to the surface of the plates by means of a chromatography spray. Colonies were scored 7 days after the delayed addition of adenine. 
Results for untreated cells of mutant ad-1,40, and for cells treated with nitrous acid, are shown in Fig. 4. From this graph it can be seen that a decrease in viable count is more rapid on minimal medium supplemented with methionine than on plates of unsupplemented minimal medium. This result is probably due to the fact that on minimal medium plus methionine each colony-forming unit contains fewer cells, because of decreased residual divisions, than is the case on minimal medium. It must be pointed out that of necessity these differential survival experiments were carried out at a much lower plating density than is used for the scoring of revertant colonies. On the actual plates on which $\mathrm{ad}^{+}$colonies are scored the extent of differential survival may be different from that described above.

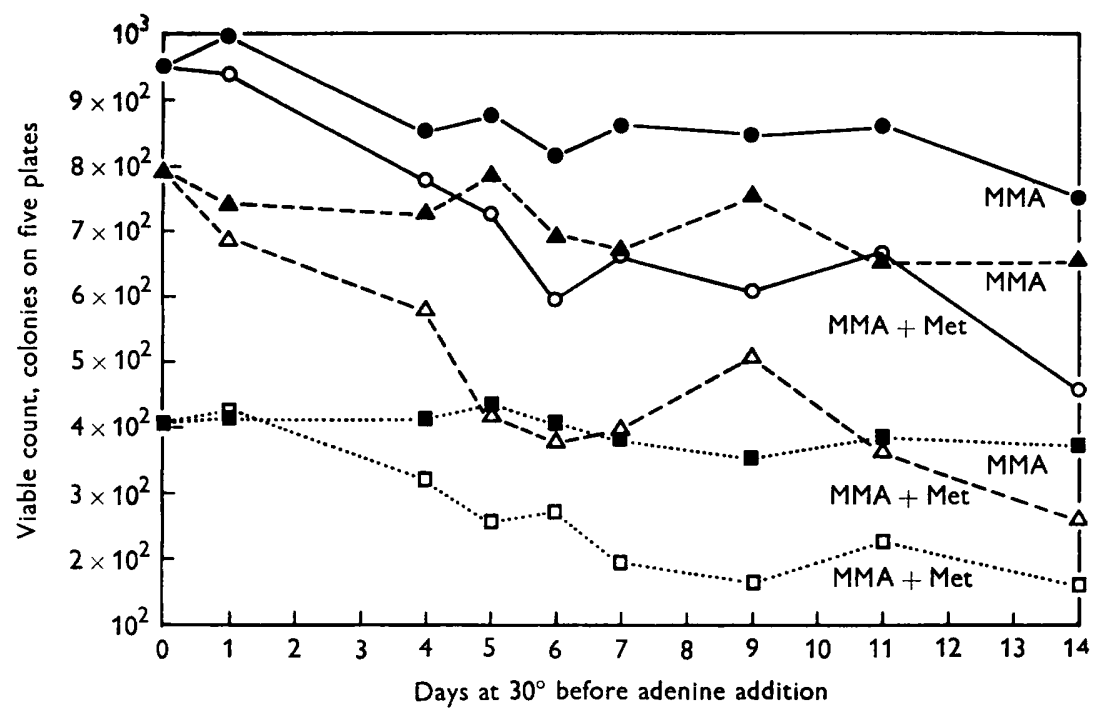

Fig. 4. The differential survival of untreated and $\mathrm{HNO}_{\mathrm{a}}$-treated cells of ad-1, 40 on minimal medium (MMA) and minimal medium plus methionine (MMA + Met). Cells were plated at a density of about 100-200 viable cells per plate. The plates were incubated at $30^{\circ}$ and at intervals received delayed addition of adenine. Colonies were scored 7 days following adenine addition. Viable count is plotted against number of days incubation before delayed adenine addition. - Untreated cells incubated on MMA plates. $\bigcirc-O$ Untreated cells incubated on MMA + Met. $\Delta--\Delta \mathbf{H N O}_{2}$-treated cells $(83 \%$ survival) incubated on MMA plates. $\triangle--\triangle \mathrm{HNO}_{2}$-treated cells $(83 \%$ survival) incubated on MMA + Met plates. $\cdots \cdot \cdots \mathrm{HNO}_{2}$-treated cells (42 \% survival) incubated on MMA plates. $\square \cdots \square \mathrm{HNO}_{2}$-treated cells (42\% survival) incubated on MMA+Met plates.

Influence of methionine upon other revertants. Tests were made to determine whether or not the presence of methionine in the plating medium would suppress the appearance of revertants at loci other than adenine-1. An adenine auxotroph, $a d-D 2$, which is blocked at one of the first two steps between the formation of 5-aminoimidazole ribotide and inosinic acid (Leupold, 1961), was tested. This mutant accumulates a red pigment when grown in the presence of limiting concentrations of adenine. Spontaneous revertants of $a d-D 2$ and revertants induced by nitrous acid appeared to be suppressed by the addition of methionine to the minimal medium. The appearance of large colony revertants of the leucine auxotroph leu-3, 241 induced by nitrous acid was also inhibited when platings were made on minimal medium plus methionine. 
Minute colony revertants which are scored after 15 days' incubation at $30^{\circ}$ do not appear to be inhibited by the presence of methionine. These minute colony revertants are due to suppressor mutations at loci other than that of the original mutant (Heslot, 1962). Tests were made with spontaneous minute colony revertants, and such revertants induced by treatment with di-ethyl sulphate, ethyl methane sulphonate, and di-epoxybutane. The arginine auxotroph $\arg -1,230$, the leucine auxotroph leu-3, 241 and the uracil auxotroph ura-1, 171 were employed in these experiments, some of which were performed with Dr H. Heslot. Methionine apparently had no influence on the expression of minute colony (suppressor) revertants of the above auxotrophs, as is shown in Table 2.

Table 2. Influence of methionine upon slow growing suppressor reversions (15-day counts)

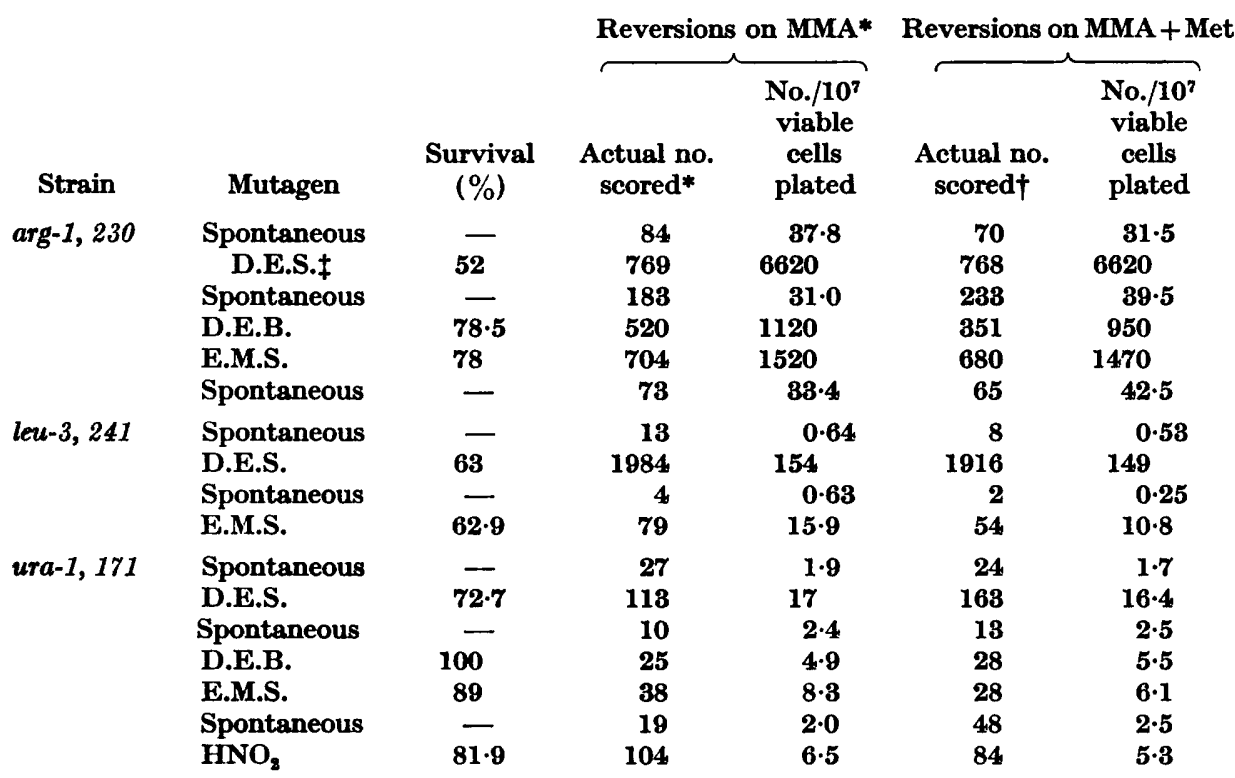

* $M M A=$ minimal medium agar. MMA+Met $=$ minimal medium agar $+\mathrm{L}-$ methionine, $40 \mu \mathrm{g} . / \mathrm{ml}$.

$\dagger$ Actual numbers of slow growing revertant colonies scored, uncorrected for cases in which all the plates in a series could not be scored.

† D.E.S. = di-ethyl sulphate. D.E.B. = di-epoxybutane.

E.M.S. = ethyl methane sulphonate.

Influence of other amino acids on the expression of reversions. A few experiments were performed with $a d^{-}$mutants in which platings for $a d^{+}$revertants were made on minimal medium supplemented with L-histidine $(40 \mu \mathrm{g} . / \mathrm{ml}$.) or L-leucine $(200 \mu \mathrm{g} . / \mathrm{ml}$.). Both these amino acids appeared to have no influence on revertants of either $a d-1,40$ or $a d-D 2$. Results are shown in Table 3. Clavilier, Luzzati \& Slonimski (1960) likewise found histidine to be without effect on reverse mutations of ad-3 mutants in haploid strains of Saccharomyces cerevisiae. 
Table 3. Influence of histidine and leucine on $\mathrm{ad}^{+}$reversions

\begin{tabular}{|c|c|c|c|c|c|c|c|c|}
\hline & & & & & $A d^{+}$reve & sions on & & \\
\hline & & & & $\mathbf{L} \mathbf{A}^{*}$ & MM & + His & $\mathbf{M M}$ & + Leu \\
\hline Mutant & Mutagen & $\begin{array}{c}\text { Survival } \\
(\%)\end{array}$ & $\begin{array}{c}\text { Actual } \\
\text { no.t } \\
\text { of } a d^{+}\end{array}$ & $\begin{array}{c}A d^{+} / 10^{7} \\
\text { viable } \\
\text { cells } \\
\text { plated }\end{array}$ & $\begin{array}{c}\text { Actual } \\
\text { no. } \dagger \\
\text { of } a d+\end{array}$ & $\begin{array}{c}A d^{+} / 10^{7} \\
\text { viable } \\
\text { cells } \\
\text { plated }\end{array}$ & $\begin{array}{c}\text { Actual } \\
\text { no. }{ }^{-} \\
\text {of } a d^{+}\end{array}$ & $\begin{array}{c}A d^{+} / 10^{2} \\
\text { viable } \\
\text { cells } \\
\text { plated }\end{array}$ \\
\hline ad-1, 40 & $\begin{array}{l}\text { Spontaneous } \\
\text { HNO }_{2} \\
\text { Spontaneous } \\
\text { HNO, }_{2}\end{array}$ & $\begin{array}{c}\overline{54 \cdot 2} \\
\frac{-}{82}\end{array}$ & $\begin{array}{r}4 \\
11 \\
32 \\
65\end{array}$ & $\begin{array}{l}0 \cdot 57 \\
2 \cdot 89 \\
\mathbf{3} \cdot 4 \\
\mathbf{8} \cdot 45\end{array}$ & $\begin{array}{r}7 \\
17 \\
30 \\
74\end{array}$ & $\begin{array}{l}1 \cdot 0 \\
4 \cdot 45 \\
8 \cdot 19 \\
9 \cdot 6\end{array}$ & $\begin{array}{r}4 \\
10 \\
41 \\
72\end{array}$ & $\begin{array}{l}0 \cdot 57 \\
2 \cdot 62 \\
4 \cdot 35 \\
\mathbf{9 \cdot 3 5}\end{array}$ \\
\hline$a d-D 2$ & $\begin{array}{l}\text { Spontaneous } \\
\mathrm{HNO}_{2}\end{array}$ & $\overline{41 \cdot 8}$ & $\begin{array}{r}0 \\
13\end{array}$ & $\begin{array}{l}0 \\
8 \cdot 2\end{array}$ & $\begin{array}{r}\mathbf{8} \\
15\end{array}$ & $\begin{array}{l}0 \cdot 63 \\
7 \cdot 6\end{array}$ & $\begin{array}{r}\mathbf{3} \\
\mathbf{1 1}\end{array}$ & $\begin{array}{l}0 \cdot 63 \\
5 \cdot 56\end{array}$ \\
\hline$a d-1,199$ & $\begin{array}{l}\text { Spontaneous } \\
\mathrm{HNO}_{2}\end{array}$ & $\begin{array}{r}- \\
105 \\
101 \\
90 \\
79 \\
102 \\
91 \\
90 \\
84 \\
89\end{array}$ & $\begin{array}{r}9 \\
25 \\
45 \\
74 \\
93 \\
95 \\
98 \\
111 \\
117 \\
122\end{array}$ & $\begin{array}{c}1 \cdot 52 \\
4 \cdot 06 \\
7 \cdot 57 \\
14 \cdot 0 \\
20 \cdot 0 \\
15 \cdot 8 \\
17 \cdot 4 \\
21 \cdot 0 \\
23 \cdot 7 \\
23 \cdot 5\end{array}$ & $\begin{array}{r}8 \\
20 \\
31 \\
44 \\
84 \\
88 \\
82 \\
106 \\
88 \\
108\end{array}$ & $\begin{array}{c}1 \cdot 36 \\
3 \cdot 26 \\
5 \cdot 21 \\
10 \cdot 4 \\
18 \cdot 0 \\
13 \cdot 8 \\
15 \cdot 3 \\
20 \cdot 0 \\
16 \cdot 8 \\
20 \cdot 8\end{array}$ & $\begin{array}{l}- \\
- \\
- \\
- \\
- \\
-\end{array}$ & $\begin{array}{l}- \\
- \\
- \\
- \\
- \\
-\end{array}$ \\
\hline
\end{tabular}

\section{DISCUSSION}

Reverse mutation experiments are fraught with difficulties of interpretation because survival and mutations are scored under quite different conditions of medium and plating density. Interpretation of the results of experiments with microbial strains having several markers are equally difficult because the different types of reverse mutation are scored on media supplemented in different ways. The work of Glover (1956) in which he found dramatic effects of the introduction of a new marker upon the mutability of a given mutant was complicated by plating medium differences. The explanation of the loss of u.v. mutability of a tryptophan $\left(t r y^{-}\right)$mutant when a marker for streptomycin dependence $(s t r-d)$ was introduced into the same strain (Witkin \& Theil, 1960) is again complicated by differences of plating medium. In the original try- strain try ${ }^{+}$reversions were scored on supplemented minimal medium. In the $t r y^{-} s t r-d$ strain, however, try ${ }^{+}$revertants were scored on supplemented minimal medium plus streptomycin.

Zetterberg (1960), working with Ophiostoma multiannulatum, found some evidence for the influence of a met marker upon mutability of a uracil auxotroph, but was later able to exclude an influence of methionine upon the expression of ura ${ }^{+}$ revertants (Zetterberg, 1962).

Auerbach \& Kølmark (1960) were able to show that the different plating media were certainly not mainly responsible for the mutagen specificity found in an adenine-less $\left(a d^{-}\right)$, inositol-less $\left(\right.$inos $\left.^{-}\right)$di-auxotroph of Neurospora crassa. They tested the 
influence of inositol on revertants of the singly auxotrophic $a d^{-}$strain, and the influence of adenine on the inos $^{-}$strain.

In the present case there was no influence of methionine upon the survival of $a d^{-}$cells in the presence of adenine, but only upon revertant expression. The extent to which supplementation with $\mathrm{L}$-methionine at $40 \mu \mathrm{g}$. $/ \mathrm{ml}$. of the minimal medium inhibits expression of $a d^{+}$reversions depends not only on the particular mutant tested, but also upon the mutagen used to induce reversions. For mutant ad-1, 199 treated with $\mathrm{HNO}_{2}$ a total of $922 \mathrm{ad}^{+}$colonies were scored on minimal medium, and 735 on minimal plus methionine. For u.v.-induced revertants of the same mutant, $345 \mathrm{ad}^{+}$colonies arose on minimal, 20 on minimal plus methionine medium. This difference in suppression of $\mathrm{HNO}_{2}$ - and u.v.-induced reversions of $a d-1,199$ is highly significant at the $1 \%$ level (Clarke, 1962). Similarly there is a difference significant at the $1 \%$ level in the degree of methionine suppression of u.v.-induced revertants of the two mutants $a d-1,40$ and $a d-1,199$. These results may be due to the fact that mutant 199 is temperature sensitive, being adenine-requiring at $30^{\circ}$, but adenineindependent at $25^{\circ}$.

It is not known if suppression of reversions is a direct consequence of impaired residual divisions, or if depression of revertants and residual divisions are both features of an underlying biochemical effect. Methionine metabolism has been shown to interact with adenine biosynthesis in Saccharomyces cerevisiae (Lindegren, 1949; Woodward \& Rainbow, 1961). However, in the present experiments reversions induced by nitrous acid treatment of a leucine auxotroph were also depressed in the presence of methionine. Since the slow-growing suppressor revertants of auxotrophs leu-3, 241, arg-1, 230, and ura-1, 171 were not inhibited by methionine, it might be thought that methionine only inhibited the expression of true reverse mutations, but not that of reversions due to suppressor mutations. However, it has recently been found (Clarke, unpublished results) that spontaneous revertants of $a d-1,40$, susceptible to methionine inhibition, are often due to suppressors. The possibility still remains that methionine only inhibits the expression of revertants showing rapid growth on minimal medium, but not of minute colony, slowly growing revertants.

A somewhat similar case of a plating medium effect involving an amino acid has been described by Luzzati, Clavilier \& Slonimski (1959). Histidine was found to exert a depressive effect on non-reciprocal recombination (gene conversion) giving rise to prototrophs at the adenine-histidine (ad-3) locus in Saccharomyces cerevisiae. The inhibitory effect of histidine was counteracted by very low concentrations of adenine.

It is not known if the inhibitory action of methionine upon $a d^{+}$reversions in Schizosaccharomyces pombe is similarly counteracted by adenine, or if amino acids other than methionine have a similar suppressive effect. The results indicate, however, that plating medium effects may explain some cases of apparent influence of the genetic background on mutability.

I wish to thank Dr Charlotte Auerbach, F.R.S., for her invaluable advice, interest and encouragement, and Drs G. Kølmark and B. J. Kilbey for helpful discussions and criticism. I am indebted to Professor U. Leupold, Dr H. Heslot and Mr R. B. Drysdale for kindly providing strains, and to Mr G. Bond, who performed some of the ultraviolet experiments. 
The work was supported by the Medical Research Council and by U.S. Public Health Service grant RG-6237(CL).

\section{REFERENCES}

Auerbach, C. \& Kølmark, G. (1960). Mutagen specificity and combination treatments in Neurospora. Microbiol. Gen. Bull. 17, 23.

Bertani, G. (1951). A method for detection of mutations using streptomycin dependence in Escherichia coli. Genetics, 36, 598.

Clarke, C. H. (1962). A case of mutagen specificity attributable to a plating medium effect. Z. Vererb.-Lehre, 93, 435.

Clavilier, L., Luzzati, M. \& Slonimski, P. P. (1960). Sur la conversion du gène ad 3 chez la levure. C.R. Soc. Biol., Paris, 154, 1970.

Fritz-Niggli, H. (1960). Röntgenstrahleninduzierte Rückmutationen (Punktmutationen) bei Schizosaccharomyces pombe in Abhängigkeit vom Zellzustand, Bestrahlungsmilieu und Agens der Vorwärtsinduktion. Naturwissenschaften, 18, 429.

Giese, A. C., Iverson, R. M. \& Sanders, R. T. (1957). Effect of nutritional state and other conditions on ultra-violet resistance and photoreactivation in yeast. J. Bact. 74, 271.

Glover, S. W. (1956). A comparative study of induced reversions in Escherichia coli. Publ. Carneg. Instn, 612, 121.

GrigG, G. W. (1952). Back mutation assay in micro-organisms. Nature, Lond. 169, 98.

Heslot, H. (1960). Schizosaccharomyces pombe: un nouvel organisme pour l'étude de la mutagenèse chimique. Abh. dtsch. Akad. Wiss. Berl., Klasse Medizin, 1, 98.

HesLot, H. (1962). Etude quantitative de reversions biochimique induites chez la levure Schizosaccharomyces pombe par des radiations et des substances radiomimetiques $A b h$. dtsch. Akad. Wiss. Berl., Klasse Medizin, 1, 193.

LEUPOLD, U. (1955). Versuche zur genetischen Klassifizierung adeninabhängiger Mutanten von Schizosaccharomyces pombe. Arch. Klaus-Stift. VererbForsch. 30, 506.

LEUPOLD, U. (1958). Studies on recombination in Schizosaccharomyces pombe. Cold Spr. Harb. Symp. quant. Biol. 23, 161.

Leupold, U. (1961). Intragene Rekombination und allele Komplementierung. Arch. Klaus-Stift. VererbForsch. 36, 89.

Lindegren, C. C. (1949). The Yeast Cell: Its Genetics and Cytology, Chap. 15. St Louis: Educational Publishers Inc.

Luzzati, M., Clavilner, L. \& Slonimski, P. P. (1959). Inhibition par l'histidine de la réversion prototrophe chez la levure diploide hétéroallélique pour le locus adéninehistidine. C.R. Acad. Sci. Paris, 249, 1412.

MrYAKE, T. (1960). Mutator factor in Salmonella typhimurium. Genetics, 45, 11.

READER, V. (1927). The relation of the growth of certain micro-organisms to the composition of the medium. I. The synthetic culture medium. Biochem. J. 21, 901 .

Rudner, R. (1961). Mutation as an error in base pairing. I. The mutagenicity of base analogues and their incorporation into the DNA of Salmonella typhimurium. Z. Vererb.Lehre, $92,336$.

Treffers, H. P., Spinelli, V. \& Belser, N. O. (1954). A factor (or mutator gene) influencing mutation rates in Escherichia coli. Proc. nat. Acad. Sci., Wash. 40, 1064.

Wirkin, E. M. \& Theil, E. C. (1960). The effect of post-treatment with chloramphenicol on various ultraviolet induced mutations in Escherichia coli. Proc. nat. Acad. Sci., Wash. 46, 226.

Woodward, J. D. \& RaInbow, C. (1961). 5-aminoimidazole and its riboside from biotindeficient yeast. J. gen. Microbiol. 25, 141.

Zetrerserg, G. (1960). The mutagenic effect of 8-ethoxycaffein caffein and dimethylsulphate in the Ophiostoma back-mutation test. Hereditas, 46, 279.

ZetTerberG, G. (1962). Genetic influence on the back-mutation rate in biochemical mutant strains of Ophiostoma. Exp. Cell Res. 27, 560. 